\title{
The Utility of the Callosal/Supratentorial-Supracallosal Area Ratio to Evaluate Corpus Callosum Morphometry in Children
}

\section{Çocuklarda Kallosal/Supratentoryal-Suprakallosal Alan Oranının Korpus Kallosum Morfometrisini Değerlendirmede Yararlıı̆ı}

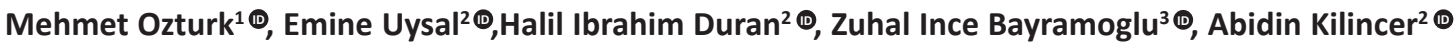

${ }^{1}$ Selcuk University Faculty of Medicine, Division of Pediatric Radiology, Konya, Turkey

${ }^{2}$ Selcuk University Faculty of Medicine, Department of Radiology, Konya, Turkey

${ }^{3}$ Istanbul Faculty of Medicine, Division of Pediatric Radiology, Konya, Turkey

Received: 22.07.2020 / Accepted: 08.10.2020 / Published Online: 29.12.2020

Cite as: Ozturk M, Uysal E, Duran HI, Ince Bayramoglu Z, Kilincer A. The utility of the callosal/supratentorial-supracallosal area ratio to evaluate corpus callosum morphometry in children. Med J Bakirkoy 2020;16(4):399-405.

\section{ABSTRACT}

Objective: To perform morphometric analysis of corpus callosum (CC) by using callosal area (CA), supratentorial-supracallosal area (SSA) and CA/SSA parameters in a healthy pediatric population and to investigate changes according to age and gender. Method: Method: This retrospective study included a total of 313 children (154 boys, 159 girls) aged between 3-17 years. The cases were divided into three groups according to age: 3-6 years (Group 1) (pre-school), 7-12 years (Group 2) (preadolescent) and 13-17 years (Group 3) (adolescent). CA and SSA were measured on the mid-sagittal plane on T1-weighted images. CA/ SSA index was calculated. Differences in age, CA, SSA, and ratio parameters among the gender groups were compared using the Mann-Whitney $U$ or the t-test.

Results: Median values of CA $(p=0.002)$, mean values of SSA $(p=0.001)$ and CA/SSA ratios $(p=0.04)$ were significantly higher in boys compared to girls. The median CA and mean CA/SSA ratios in Group 3 were significantly higher than Groups 1 and 2 $(p=0.001)$. Mean CA/SSA ratio values of boys and girls in Age Group 3 were significantly higher than Group $1(p=0.001)$ and significantly higher than Age Group 2 in girls. There were highly significant positive correlations of age with CA ( $p=0.001$, $r=0.47), S S A(p=0.028, r=0.12)$ and CA/SSA ratio $(p=0.001, r=042)$. There was a highly significant and positive correlation between CA and SSA ( $p=0.001, r=0.25)$ and CA $S S A$ ratio $(p=0.001, r=0.87)$.

Conclusion: CA, SSA, and CA/SSA ratio values in children are affected by age and gender. These parameters can be used as reference values for the diagnosis of congenital and acquired pathologies affecting the corpus callosum.

Keywords: Corpus callosum, morphometry, children, magnetic resonance imaging

Öz

Amaç: Sağlıklı bir pediyatrik popülasyonda kallozal alan (KA), supratentoryal-suprakallosal alan (SSA) ve KA / SSA parametrelerini kullanarak korpus kallozum (KK)'un morfometrik analizini yapmak ve yaş ve cinsiyete göre değişimi araştırmak.

Yöntem: Bu retrospektif çalışma, 3-17, 154 erkek ve 159 kız arasında toplam 313 çocuğu kapsamaktadır. Olgular yaşa göre üç gruba ayrıldı: 3-6 yaş (Grup 1) (okul öncesi), 7-12 yaş (Grup 2) (preadolesan) ve 13-17 yaş (Grup 3) (ergen). KA ve SSA, T1 ağırlıklı görüntülerde sagittal düzlemde ölçüldü. KA / SSA indeksi hesaplandı. Cinsiyet grupları arasındaki yaş, KA, SSA ve oran parametrelerindeki farklılıklar "Mann-Whitney U" veya t testi kullanılarak karşılaştırıldı.

Bulgular: Ortalama medyum (çeyrekler arası aralık) değerleri $K A(p=0,002)$ ve ortalama SSA değerleri $(p=0,001)$ ve $K A / S S A$ oranları $(p=0,04)$ erkeklerde kızlara göre anlamlı olarak daha yüksekti. Grup 3'teki ortanca KA ve ortalama KA / SSA oranları grup 1 ve 2'den anlamlı olarak yüksekti $(p=0,001)$. Grub 3'deki kız ve erkeklerin ortalama KA / SSA oranı değerleri Grup 1'den anlamlı olarak yüksek ( $p=0,001)$ ve kızlarda yaş grubu 2'den anlamlı olarak daha yüksekti. $K A(p=0,001, r=0,47), S S A(p=0,028$, $r=0,12)$ ve $K A$ / SSA oranı $(p=0,001, r=0,42)$ ile yaş arasında anlamlı pozitif korelasyon vardı. KA ile SSA $(p=0,001, r=0,25)$ ve $K A / S S A$ oranı $(p=0,001, r=0,87)$ arasında yüksek derecede anlamlı pozitif korelasyon vardı

Sonuç: Cocuklarda KA, SSA ve KA / SSA oranı değerleri yass ve cinsiyetten etkilenmektedir. KK'u etkileyen konjenital ve edinilmiş patolojilerin tanısında referans değerler olarak kullanılabilir.

Anahtar kelimeler: Korpus kallozum, morfometri, çocuklar, manyetik rezonans görüntüleme

Corresponding Author:

drmehmet2121@gmail.com
M. Ozturk 0000-0001-5585-1476

E. Uysal 0000-0001-8533-4939

H.I. Duran 0000-0001-7091-798X
Z. Ince Bayramoğlu 0000-0002-1695-3290 A. Kilincer 0000-0001-6027-874X 


\section{INTRODUCTION}

The corpus callosum (CC) is a commissural structure consisting of nerve fibers that provide the connection between the cortical and subcortical neurons of the two cerebral hemispheres ${ }^{(1)}$. This white matter structure, consisting of at least 200-300 million fibers, is critical for the transfer of sensory, motor and cognitive information (2). The CC anatomically consists of four parts: rostrum, genu, body and splenium. While other parts of the CC develop in the intrauterine 8th to 20 th weeks, the rostrum develops $18-20$ weeks after postconceptional age ${ }^{(3)}$. The main determinant of CC size is the degree of myelination of the fibers. There is rapid growth within the first 1-4 years after birth and can continue until the third decade of life ${ }^{(4)}$.

In recent years, many morphometry studies have been published investigating the relationship between the appearance of clinical signs of various developmental disorders and pathological conditions and the morphology of the CC ${ }^{(5-7)}$. Different pathological processes such as mental disorders, dyslexia, autism, speech dysfunction, seizure, and Alzheimer's disease were shown to cause changes in the morphology of the CC (8-10). Different measurement methods and studies published have shown that the shape and dimensions of the $\mathrm{CC}$ can vary according to age, gender, size of the brain and societies ${ }^{(11,12)}$. In one of these methods, Erdoğan N, et al. reported a morphometric index defined by the proportion of callosal area (CA) and supratentorial-supracallosal areas (SSAs) ${ }^{(13)}$. The described index was used in the adult population and reported to be a reliable tool in the morphometric analysis of the CC for the evaluation of conditions such as developmental deficiency (hypogenesis) or widespread loss of white matter ${ }^{(13)}$. However, there are not enough scientific studies about the use of this index in childhood.

This study aims to perform morphometric analysis of $\mathrm{CC}$ and investigate its change by age and gender using CA, SSA and CA/SSA parameters in healthy pediatric and adolescent populations.

\section{MATERIAL and METHODS}

\section{Study Design and Subject Selection}

This study was approved by the local ethics committee and the study was carried out in accordance with the principles of Helsinki Declaration. Since the study was conducted retrospectively, "informed consent" was not received from the parents. No personal information about the cases was given and the radiological images were presented anonymously. In this retrospective study conducted in a single center between JanuaryMay 2020, the brain MRI of a total of 313 cases including 154 boys and 159 girls aged 3-17 years, were examined.

The MR imaging examinations were performed in children presenting with findings possibly associated with cerebral pathology including for example, headache, seizures, myoclonia, dizziness, balance disorders, abnormal visual findings, deafness, precocious puberty, facial palsy, scalp midline mass or cyst without any cerebral abnormality. Children with metabolic or neuropsychological disorders, cerebral mass, cerebral malformation, trauma, cranial hematoma or hypoxic injury, intracranial hemorrhage, edema, hydrocephalus, cranial malformation, cerebral atrophy and multiple extracerebral malformations, any pathologic cranial findings, premature birth, and insufficient image quality were excluded from the study. The cases were divided into three groups according to age: 3-6 years (Group 1) (preschool), 7-12 years (Group 2) (preadolescent) and 13-17 years (Group 3) (adolescent).

\section{MRI Technique and Image Analysis}

The MRI examination was performed using a 1.5-T imager (Siemens Magnetom Aera; Siemens AG Healthcare Sector, Erlangen, Germany) with a standard head coil. From the survey scans, T1-weighted (T1-W) mid-sagittal sections through the anterior and posterior commissures and axial sections through the third ventricle were obtained for measurements. Parameters for T1-W images were as follows: FOV: $230 \mathrm{~mm}$, matrix: $256 \times 256$, slice thickness: $5 \mathrm{~mm}$, interslice gap: $1 \mathrm{~mm}$, NEX: 2- 3, TR/ TE: 562/ 14 msec. FLAIR sequence was obtained to exclude cases where pathological signal changes might occur.

Evaluation of MRI was performed by a pediatric radiologist with more than 8 years of pediatric neuroradiology experience. Firstly, the section showing the $\mathrm{CC}$ and SSA parenchyma in midsagittal T1-W images was selected for evaluation. The borders of the CA and SSA were drawn free-hand separately (Figure $1 \mathrm{a}, \mathrm{b}$ ). During the drawing, special attention was paid to the lines 
passing through the boundary of the dura and calvarium in order not to affect the results of cortical gray matter changes. The calculation of the area was done automatically by the device. The index was calculated by proportioning the resulting field values.

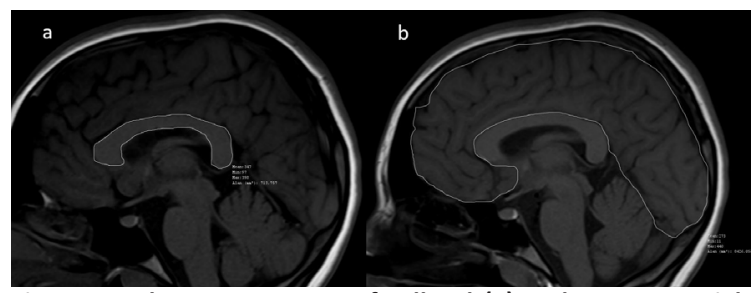

Figure $1 \mathrm{a}, \mathrm{b}$. Measurement of callosal (a) and supratentorialsupracallosal (b) area in mid-sagittal plane on T1-weighted MR images

\section{Statistical Analysis}

All data were processed in Microsoft Office Excel and transferred to SPSS (version 21.0, IBM Corp.) for statistical analysis. The distribution of the data was assessed with the Kolmogorov-Smirnov test paying attention to skewness and kurtosis. Descriptive statistics of the data were expressed as mean \pm standard deviation or median with interquartile range (IQR). Differences in age, CA, SSA, and ratio parameters among the gender groups were compared using the Mann-Whitney $U$ or the t-test. Differences in age, CA, SSA, and ratio parameters among the three age groups were compared using the Kruskal-Wallis or ANOVA test. A comparison between two age groups was assessed using the MannWhitney $U$ or the t-test. Correlation analysis of the age, CA, SSA, and ratio parameters were tested with Spearman's correlation analysis. Box-plot graphics demonstrating CA, SSA, and CA/SSA ratio by age groups were plotted (Graphic 1).

The scattered dot graph was plotted for correlation of age with the CA, SSA, and CA/SSA ratio parameters (Graphic 2). Regression equations were obtained with linear regression analysis. Variables were studied at the 95\% confidence interval, and $p$-values below 0.05 were considered statistically significant.
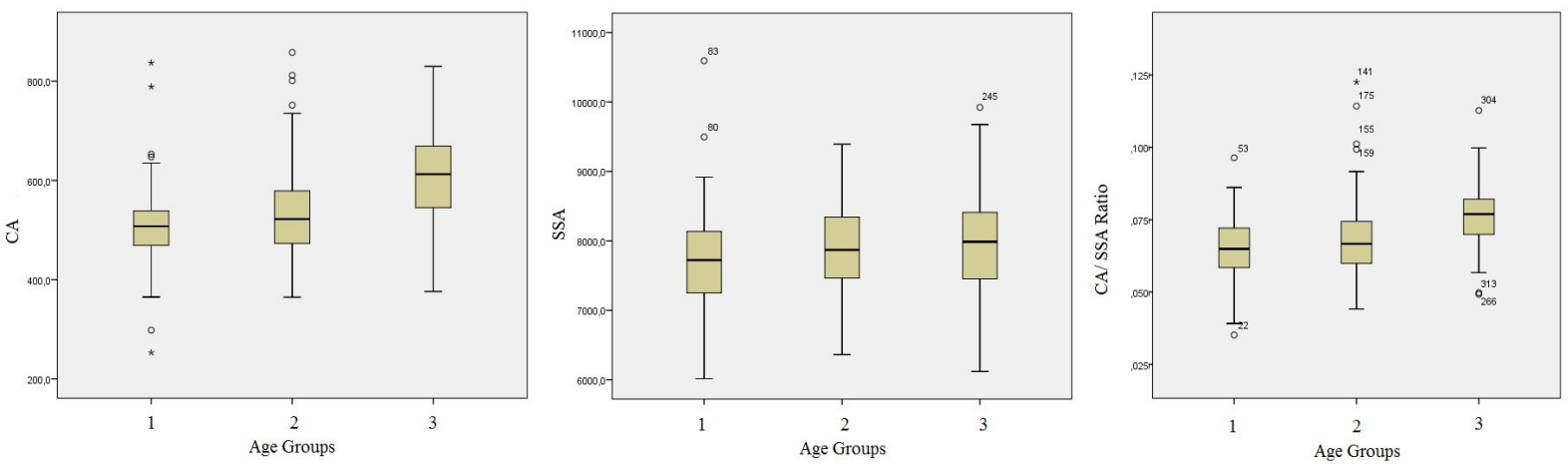

Graphic 1. Spearman's correlation analysis. Box-plot graphics demonstrating CA, SSA, and CA/SSA ratio by age groups
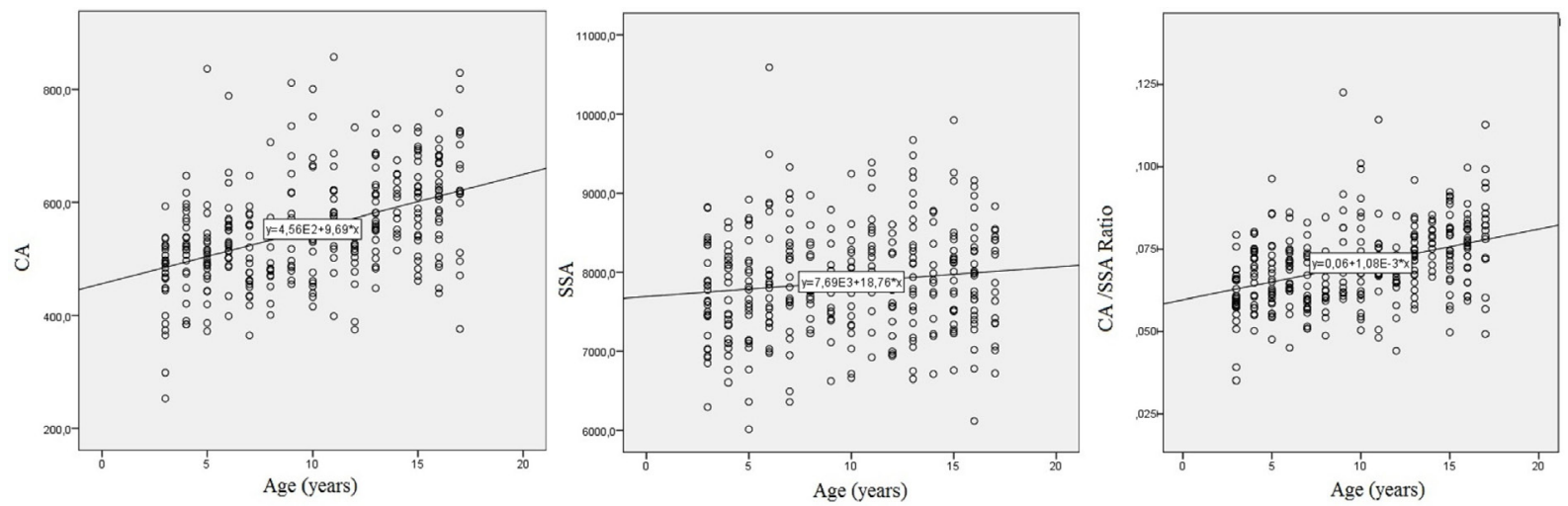

Graphic 2. The scattered dot graph. Correlation of age with the CA, SSA, and CA/SSA ratio parameters 
Table 1.Descriptive statistics of age, CA, SSA and ratio parameters by gender groups

\begin{tabular}{|c|c|c|c|}
\hline \multirow[t]{3}{*}{ Parameter } & \multicolumn{2}{|c|}{ Descriptive statistics } & $\mathbf{p}$ \\
\hline & \multicolumn{2}{|c|}{ Mean $\pm S t d$. Dev. / Median (IQR) } & \\
\hline & Girls (n: 159) & Boys (n:153) & \\
\hline Age ( years) & $10(6-15)$ & $10(5-13)$ & 0.58 \\
\hline $\mathrm{CA}\left(\mathrm{mm}^{2}\right)$ & $524(469.7-580)$ & 559 (493-641) & $0.002^{\prime}$ \\
\hline $\mathrm{SSA}\left(\mathrm{mm}^{2}\right)$ & $7734.75 \pm 628.3$ & $8018.4 \pm 732.1$ & $0.001^{*}$ \\
\hline $\begin{array}{l}\text { CA / SSA } \\
\text { Ratio }\end{array}$ & $0.069 \pm 0.011$ & $0.071 \pm 0.013$ & $0.04^{*}$ \\
\hline
\end{tabular}

$P$-values by the Mann-Whitney $U^{\prime}$ and t-test ${ }^{*}$

Bold p-values represent statistically significant results

IQR: Interquartile range

\section{RESULTS}

Descriptive statistics for age, CA, SSA, and CA/SSA ratio parameters in gender and age groups are given in Tables 1 and 2. No significant difference was found among the median ages of the males (10 [5-13]) years) and females (10 [6-15]) years) $(p=0.58)$. Median (interquartile range) values of CA ( $p=0.002)$, and mean values of SSA $(p=0.001)$ and CA/SSA ratios $(p=0.04)$ were significantly higher in boys compared to girls. There were statistically significant differences in median CA and mean CA/SSA ratios among age groups. The median CA and mean CA/SSA ratios in Group 3 were signifi-

Table 2. Descriptive statistics of age, CA, SSA, and CA / SSA ratio parameters by age groups

\begin{tabular}{|c|c|c|c|c|c|}
\hline & Group 1 & Group 2 & Group 3 & \multirow{2}{*}{\multicolumn{2}{|c|}{$\mathbf{p}$}} \\
\hline & $\begin{array}{l}\text { 3-6 years ( } \mathrm{n}: 100) \\
\text { Mean } \pm \text { Std. Dev./Median (IQR) }\end{array}$ & $\begin{array}{c}\text { 7-12 years ( } \mathrm{n}: 104) \\
\text { Mean } \pm \text { Std. Dev. / Median (IQR) }\end{array}$ & $\begin{array}{l}\text { 13-17 years ( } \mathrm{n}: 109) \\
\text { Mean } \pm \text { Std. Dev. / Median (IQR) }\end{array}$ & & \\
\hline Age (years) & $4(3-5)$ & $9(8-11)$ & $15(14-16)$ & $0.001 *$ & $\begin{array}{l}1 \text { vs } 2: 0.001^{\prime} \\
1 \text { vs } 3: 0.001^{\prime} \\
2 \text { vs } 3: 0.001^{\prime}\end{array}$ \\
\hline $\mathrm{CA}\left(\mathrm{mm}^{2}\right)$ & $507.65(468.57-538.82)$ & $522(472-579.5)$ & $612.6(543.9-670.2)$ & $0.001^{*}$ & $\begin{array}{l}1 \text { vs } 2: 0.09^{\prime} \\
1 \text { vs } 3: 0.001^{\prime} \\
2 \text { vs } 3: 0.001^{\prime}\end{array}$ \\
\hline $\mathrm{SSA}\left(\mathrm{mm}^{2}\right)$ & $7745.6 \pm 704.3$ & $7901.8 \pm 650.5$ & $7966.92 \pm 712.36$ & $0.062^{\S}$ & - \\
\hline CA / SSA Ratio & $0.065 \pm 0.01$ & $0.068 \pm 0.013$ & $0.076 \pm 0.01$ & $0.001^{\S}$ & 1 vs2: $0.17^{\prime \prime}$ \\
\hline
\end{tabular}

P-values by the Kruskal Wallis* and Mann-Whitney U' or ANOVA ${ }^{\S}$ and t-test"

Bold p-values represent statistically significant results

Table 3. Comparison of mean/ median values of age, CA, SSA and CA / SSA ratio parameters in boys and girls by age groups

\begin{tabular}{|c|c|c|c|c|c|c|}
\hline & & \multicolumn{3}{|c|}{ Age groups } & \multirow{2}{*}{\multicolumn{2}{|c|}{$p$}} \\
\hline & & $\begin{array}{c}\text { Group } 1 \\
\text { 3-6 years }(\mathrm{n}: 50) \\
\text { Mean } \pm \text { Std. Dev/ Median (IQR) }\end{array}$ & $\begin{array}{c}\text { Group } 2 \\
7-12 \text { years ( } \mathrm{n}: 52) \\
\text { Mean } \pm \text { Std. Dev/ Median (IQR) }\end{array}$ & $\begin{array}{c}\text { Group } 3 \\
\text { 13-17 years ( } \mathrm{n}: 57) \\
\text { Mean士Std. Dev/ Median (IQR) }\end{array}$ & & \\
\hline \multirow[t]{2}{*}{$\begin{array}{l}\text { Age } \\
\text { (years) }\end{array}$} & Girls & $5(4-6)$ & $9(7-11)$ & $15(14-16)$ & 0.001 & $\begin{array}{l}1 \text { vs } 2: 0.001^{\prime \prime} \\
1 \text { vs } 3: 0.001^{\prime \prime} \\
2 \text { vs } 3: 0.001^{\prime \prime}\end{array}$ \\
\hline & Boys & $4(3-5)$ & $9.5(8-11)$ & $15(13-16)$ & 0.001 & $\begin{array}{l}1 \text { vs } 2: 0.001^{\prime \prime} \\
1 \text { vs } 3: 0.001^{\prime \prime} \\
2 \text { vs } 3: 0.001^{\prime \prime}\end{array}$ \\
\hline \multirow[t]{2}{*}{$\begin{array}{l}\text { CA } \\
\left(\mathrm{mm}^{2}\right)\end{array}$} & Girls & $510.15(460.7-533.5)$ & $492.65(455-557.1)$ & $582.1(534.4-624.7)$ & 0.001 & $\begin{array}{l}1 \text { vs } 2: 0.84^{\prime \prime} \\
1 \text { vs } 3: 0.001^{\prime \prime} \\
2 \text { vs } 3: 0.001^{\prime \prime}\end{array}$ \\
\hline & Boys & 506.75 (474.6- 571.25) & $540.5(494-610.5)$ & $631.6(851-684.5)$ & 0.001 & $\begin{array}{l}1 \text { vs } 2: 0.07^{\prime \prime} \\
1 \text { vs } 3: 0.001^{\prime \prime} \\
2 \text { vs } 3: 0.001^{\prime \prime}\end{array}$ \\
\hline \multirow{2}{*}{$\begin{array}{l}\text { SSA } \\
\left(\mathrm{mm}^{2}\right)\end{array}$} & Girls & $7599.14 \pm 542.15$ & $7845.71 \pm 663.8$ & $7752.48 \pm 653.56$ & $0.13^{*}$ & \multirow[t]{2}{*}{-} \\
\hline & Boys & $7892.06 \pm 815.21$ & $7957.93 \pm 638.4$ & $8203.9 \pm 712.5$ & $0.08 *$ & \\
\hline \multirow[t]{2}{*}{$\begin{array}{l}\text { CA / } \\
\text { SSA } \\
\text { Ratio }\end{array}$} & Girls & $0.065 \pm 0.008$ & $0.065 \pm 0.01$ & $0.075 \pm 0.01$ & $0.001 *$ & $\begin{array}{l}1 \text { vs } 2: 0.99^{\ddagger} \\
1 \text { vs } 3: 0.001^{\ddagger} \\
2 \text { vs } 3: 0.001^{\ddagger}\end{array}$ \\
\hline & Boys & $0.066 \pm 0.01$ & $0.072 \pm 0.015$ & $0.077 \pm 0.01$ & $0.001^{*}$ & $\begin{array}{l}1 \text { vs } 2: 0.054^{\ddagger} \\
1 \text { vs } 3: 0.001^{\ddagger} \\
2 \text { vs } 3: 0.092^{\ddagger}\end{array}$ \\
\hline
\end{tabular}

P-values by the Kruskal Wallis* and Mann-Whitney $U^{\prime}$ or ANOVA ${ }^{\S}$ and t-test"

Bold p-values represent statistically significant results 
cantly higher than Groups 1 and 2 ( $p=0.001)$. No significant differences were found in median CA and mean CA/SSA ratios in Age Groups 1 and 2. No significant differences were found in mean SSA values among age groups $(p=0.062)$.

Because of significant differences among gender groups, we assessed the descriptive statistics and comparisons among age groups paying attention to the genders in each age group. Descriptive statistics of the age, CA, SSA, and CA/SSA ratio parameters in boys and girls by Age Group are given in Table 3. The median values of CA in both boys and girls in Age Group 3 were significantly higher than age groups 1 and $2(p=0.001)$. However, there were no significant differences in median CA values of boys and girls between Age Groups 1 and 2. There were no significant differences in mean SSA values of boys and girls among the age groups. Mean CA/SSA ratio values of boys and girls in Age Group 3 were significantly higher than Age Group $1(p=0.001)$ and significantly higher than Age Group 2 for girls. No significant difference was found in CA/SSA ratios of boys and girls between age groups 1 and 2 .

Correlation of age, CA, SSA and CA/SSA ratio parameters along with linear regression equations are given in Table 4 . There were highly significant positive correlations of age with CA $(p=0.001, r=0.47)$, SSA ( $p=0.028$, $r=0.12)$ and CA/SSA ratio $(p=0.001, r=0.42)$. There were

Table 4. Correlation of age, CA, SSA and CA/SSA ratio parameters along with linear regression equations

\begin{tabular}{|l|l|l|l|}
\hline & $p$ & $\mathbf{r}$ & Regression equations \\
\hline Age- CA & 0.001 & 0.47 & $\begin{array}{l}\mathrm{CA}\left(\mathrm{mm}^{2}\right)=456+9.69 \times \text { Age } \\
\text { (years) }\end{array}$ \\
\hline Age- SSA & 0.028 & 0.12 & $\begin{array}{l}\text { SSA }\left(\mathrm{mm}^{2}\right)=7693+18.76 \times \text { Age } \\
\text { (years) }\end{array}$ \\
\hline $\begin{array}{l}\text { Age- CA/SSA } \\
\text { ratio }\end{array}$ & 0.001 & 0.42 & $\begin{array}{l}\text { CA/SSA ratio }=0.06+1.08 / 1000 \\
\text { x Age (years) }\end{array}$ \\
\hline CA-SSA & 0.001 & 0.25 & $\begin{array}{l}\text { SSA }\left(\mathrm{mm}^{2}\right)=6740+2.07 \times \text { CA } \\
\left(\mathrm{mm}^{2}\right)\end{array}$ \\
\hline
\end{tabular}

highly significant moderate positive correlations among CA with SSA $(p=0.001, r=0.25)$ and CA $/$ SSA ratio $(p=$ $0.001, r=0.87)$. Age-dependent regression equations were as follows: "CA $\left(\mathrm{mm}^{2}\right)=456+9.69 \times$ Age (years)", "SSA $\left(\mathrm{mm}^{2}\right)=7693+18.76 \times$ Age (years)", and "CA/ SSA ratio $=0.06+1.08 / 1000 \times$ Age (years)". The CA-dependent regression equation for SSA was "SSA $\left(\mathrm{mm}^{2}\right)=6740+$ 2.07x CA $\left(\mathrm{mm}^{2}\right)^{\prime \prime}$.

\section{DISCUSSION}

Corpus callosum (CC) is the main commissural structure that connects both cerebral hemispheres, and many factors may affect its morphology including developmental anomalies, myelination disorders, and degenerative, ischemic or traumatic axon losses. It affects development in association with demographic differences such as age, gender, right or left-handed dominance, and ethnic group ${ }^{(12-14)}$. In a recent study of the Turkish population with 436 adult cases, thickness and vertical length measurements were made in different sections of the $\mathrm{CC}$ and it was reported that there could be gender differences for all parameters ${ }^{(12)}$. In a study conducted in Iran, in which morphometric analyses were used based on the measurements of frontal occipital pole of the brain, longitudinal size of the brain - the genus of $\mathrm{CC}$, the occipital pole of the brain - the splenium of $\mathrm{CC}$ and the point from the posterior point of the front of $\mathrm{CC}$ to the poster length, parameters were higher in males than females ${ }^{(14)}$. WHA Ng et al. reported that the $\mathrm{CC}$ was thicker in Chinese boys than girls ${ }^{(15)}$. In two different studies using CA, SSA and CA/SSA ratio parameters in the adult population, these parameters differed according to gender and were shown to be higher in males ${ }^{(11,13)}$. In this study, CA, SSA, and CA/SSA ratio parameters were used for the first time in children and they were higher in boys in all age groups. The results were similar to previous morphometric measurements. These results may have occurred due to developmental and hormonal differences in children. In terms of providing reference data for morphometric studies, these data should be supported with future biochemical and hormonal data.

There are important differences in brain development during adolescence. White matter development is affected by sex hormones such as testosterone. The corpus callosum, the largest white matter structure in the brain, changes structurally in the pubertal period when hormonal changes occur ${ }^{(16)}$. Chavarria MC et al. reported the increase in callosal thickness progressed during adolescence in children and adolescents. In the same study, they stated that callosal parts were affected differently by pubertal growth ${ }^{(17)}$. In a morphometric analysis of the CC performed up to 15 years after birth, it has been reported that callosal length and thickness increase with age ${ }^{(18)}$. The parameters used in this study (CA, SSA, and CA/SSA ratio) increased with 
age and the highest values appeared in the adolescent period. The change with age was similar to measurements made with different parameters in previous years. However, since this study had a retrospective nature, real hormone levels could not be measured; therefore, a possible relationship between hormone levels and parameters could not be revealed. Diffusion tensor imaging (DTI) and fiber monitoring techniques allowed the CC to be separated into bands corresponding to functional units. DTI-based fiber tractography can help to show whether callosal effects are associated with cortical changes in adolescence ${ }^{(5)}$. DTI studies, along with hormonal tests in the future, will help to clarify the relationships and the underlying mechanisms between pubertal status and neurodevelopment.

There are important limitations in our study. The first is the low number of patients and that cases younger than three years old were excluded from the study. Second, since it was performed retrospectively, data about height, weight, BMI, hormone values and ethnic origin of the cases could not be obtained. Thirdly, intraobserver and inter-observer comparisons could not be made since the evaluations were made by only one observer. Finally, clinical and laboratory data used to support the fact that subjects are healthy were provided only from the electronic archive system. We cannot completely exclude potential underlying pathological changes that involve the brain parenchyma.

\section{Conclusion}

In conclusion, CA, SSA and CA/ SSA ratio parameters provide important contributions to the morphometric evaluation of $\mathrm{CC}$ in children. The depicted values vary according to age and gender. It can be used as reference values for the diagnosis of various congenital and acquired pathologies affecting the CC. Future studies will contribute to the understanding of callosal development by using hormonal tests and other radiological methods.

Ethics Committee Approval: Ethics committee approval was received for this study from the Institutional Review Board of Selcuk University (08.01.2020, 06/2020)

Conflict of Interest: The author(s) declared no potential conflicts of interest with respect to the research, authorship and/or publication of this article.

Funding: The author(s) received no financial support for the research, authorship and/or publication of this article.

Informed Consent: Written informed consent could not be obtained due to the retrospective nature of the study.

\section{REFERENCES}

1. Fundamentals of the nervous system. In: deGroot J, Chusid JG, editors. Correlative Neuroanatomy. 21st ed. Sydney: PrenticeHall; 1991. p. 1-5.

2. Sakai T, Mikami A, Suzuki J, Miyabe-Nishiwaki T, Matsui M, et al. Developmental trajectory of thecorpus callosum from infancy to the juvenile stage: comparative MRI between chimpanzees and humans. PLoS One. 2017;12:e0179624.

https://doi.org/10.1371/journal.pone.0179624

3. Karakaş P, Koç Z, Koç F, Gülhal Bozkır M. Morphometric MRI evaluation of corpus callosumand ventricles in normal adults. Neurol Res. 2011;33:1044-9.

https://doi.org/10.1179/1743132811Y.0000000030

4. Rauch RA, Jinkins JR. Analysis of cross-sectional area measurements of the corpus callosum adjusted for brain size in male and female subjects from childhood to adulthood. Behav Brain Res. 1994;64:65-78. https://doi.org/10.1016/0166-4328(94)90119-8

5. Andronikou S, Pillay T, Gabuza L, Mahomed N, Naidoo J, et al. Corpus callosum thickness in children: an MR pattern-recognition approach on the midsagittal image. Pediatr Radiol. 2015;45:258-72. https://doi.org/10.1007/s00247-014-2998-9

6. Krupa K, Bekiesinska-Figatowska M. Congenital and acquired abnormalities of the corpus callosum: a pictorial essay. Biomed Res Int. 2013;2013:265619. https://doi.org/10.1155/2013/265619

7. Luders E, Thompson PM, Toga AW. The development of the corpus callosumin the healthy human brain. J Neuroscience. 2010;30:10985-90. https://doi.org/10.1523/JNEUROSCI.5122-09.2010

8. Allouh MZ, Al Barbarawi MM, Ali HA, Mustafa AG, Alomari SO. Morphometric Analysis of the corpus callosumn According to Age and Sex in Middle Eastern Arabs: Racial Comparisons and Clinical Correlations to Autism Spectrum Disorder. Front Syst Neurosci. 2020;14:30 https://doi.org/10.3389/fnsys.2020.00030

9. Firat $A$, Tascioglu $A B$, Demiryurek MD, Saygi $S$, Oguz KK. Evaluation of corpus callosum morphometry in patients with mesial temporal lobe epilepsy with hippocampal sclerosis. Surg Radiol Anat. 2014;36:47-54 https://doi.org/10.1007/s00276-013-1144-y

10. Kabay SC, Gulbandilar E, Ozden H, Ozbag D, Guven G, Baki Adapinar, et al. Evaluation of the size and area of the corpus callosum with the Osiris method in Alzheimer's disease. Neurodegener Dis. 2009;6:148-53. https://doi.org/10.1159/000225375

11. Guz W, Pazdan D, Stachyra S, Świętoń F, Poręba P, et al. Analysis of corpus callosum size depending on age and sex. Folia Morphol. 2018:78;24-32. https://doi.org/10.5603/FM.a2018.0061

12. Arda KN, Akay S. The Relationship between corpus callosum morphometric Measurements and Age/Gender Characteristics: A Comprehensive MR Imaging Study. J Clin Imaging Sci. 2019;9:33. https://doi.org/10.25259/JCIS-13-2019

13. Erdoğan $\mathrm{N}$, Ülger $\mathrm{H}$, Tuna I, Okur A. A novel index to estimate the corpus callosum morphometry in adults: callosal/supratentorial 
supracallosal area ratio. Diagn Interv Radiol. 2005;11(4):179-81. PMID: 16320220.

14. Mohammadi MR, Zhand P, Mortazavi Moghadam B, Golalipour MJ. Measurement of the corpus callosum using magnetic resonance imaging in the North of Iran. Iran J Radiol. 2011;8(4):21823 https://doi.org/10.5812/iranjradiol.4495

15. Ng WHA, Chan YL, Au KSA, et al. Morphometry of the corpus callosumin chinese children: Relationship with gender and academic performance. Pediatr Radiol. 2005;35(6):565-71. https://doi.org/10.1007/s00247-004-1336-z
16. Hu S, Pruessner JC, Coupe P, Collins DL. Volumetric analysis of medial temporal lobe structures in brain development from childhood to adolescence. Neuroimage. 2013;74:276-87.

https://doi.org/10.1016/j.neuroimage.2013.02.032

17. Chavarria MC, Sánchez FJ, Chou YY, Thompson PM, Luders E. Puberty in the corpus callosum. Neuroscience. 2014;265:1-8. https://doi.org/10.1016/j.neuroscience.2014.01.030

18. Garel C, Cont I, Alberti C, Josserand E, Moutard ML, et al. Biometry of the corpus callosumin children: MR imaging reference data. AJNR Am J Neuroradiol. 2011;32;1436-43. https://doi.org/10.3174/ajnr.A2542 